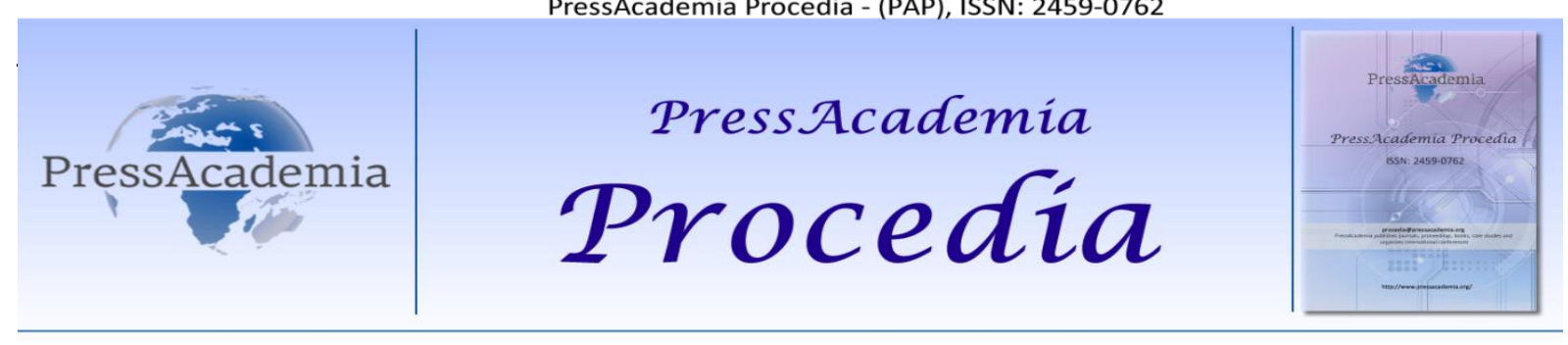

Global Business Research Congress (GBRC), May 24-25, 2017, Istanbul, Turkey.

\title{
MANDATORY MEDIATION IN LABOUR DISPUTES
}

\author{
DOI: 10.17261/Pressacademia.2017.423 \\ PAP-GBRC-V.3-2017(38)-p.378-384
}

\section{Mustafa Göksu}

Gazi University, Ankara. goksu@gazi.edu.tr

To cite this document

Göksu, M, (2017), Mandatory mediation in labour disputes, PressAcademia Procedia (PAP), V.3, p.378-384

Permanent link to this document: http://doi.org/10.17261/Pressacademia.2017.423

Copyright: Published by PressAcademia and limited licenced re-use rights only.

\begin{abstract}
It is now a well established fact that the number of disputes brought before courts and therefore the caseload of the courts are extremely high in Turkey. Labour disputes comprise a large portion of said disputes. Labour disputes, which should be dealt quickly due to their nature, might be dragged on for years in courts owing to the courts' extraordinary docket sizes. With the aim to reduce the burden on courts and promote amicable dispute resolution, the Ministry of Justice introduced the concept of mandatory mediation in certain labour disputes as part of the Labour Courts Law Draft. Early success statistics regarding modern mediation, which is in use in Turkey since 2013, was a factor in strengthening this notion. However, the idea of a mandatory use of mediation is an international subject of debate, since it must be established that whether this complies with its nature. This debate, as well as the current state of mediation in Turkey and whether this state may warrant mandatory mediation is discussed in this paper.
\end{abstract}

Keywords: Mediation, mandatory mediation, labour disputes, ADR

JEL Codes: K41, K31

\section{iş UYUŞMAZLIKLARINDA ZORUNLU ARABULUCULUK}

\section{ÖZET}

Türkiye'de mahkemelere taşınan uyuşmazlıkların ve bu sebeple de mahkemeler üzerindeki iş yükünün çok fazla olduğu artık herkesçe bilinen bir vakıadır. Bu uyuşmazlıkların en büyük kalemlerinden bir tanesini iş uyuşmazlıkları oluşturmaktadır. Nitelikleri gereği hızlı ve etkin çözülmeleri gereken bu uyuşmazlıkların sonuçlandırılması, mahkemeler üzerindeki olağanüstü iş yükü sebebiyle yıllar alabilmektedir. Bu iş yükünün azaltılması ve barış̧̧ı çözümlerin yaygınlaştııılması hedefiyle Adalet Bakanlığınca hazırlanan İ̧̧ Mahkemeleri Kanunu Tasarı Taslağı ile bazı uyuşmazlıklar bakımından zorunlu arabuluculuk kurumu gündeme getirilmiştir. Türkiye'de 2013 yılında uygulanmaya başlanan modern anlamda arabuluculuk uygulamasındaki erken başarı istatistikleri de bu düşünceye destek oluşturmuştur. Ancak arabuluculuğun zorunlu olması halinin, bu kurumun niteliği ile ne kadar bağdaşabileceği dünya uygulamasında da tartışılmaktadır. Bu çalışmada, arabuluculuk kurumunun Türkiye'deki durumu ve bu kurumun, mevcut durum da göz önünde tutularak, zorunlu bir uygulamaya müsait olup olmadığı değerlendirilmiștir.

Anahtar Kelimeler: Arabuluculuk, zorunlu arabuluculuk, iş uyuşmazlıkları, alternatif uyuşmazlık çözüm yolları JEL Kodları: K41, K31 


\section{GIRIŞ VE GENEL OLARAK ARABULUCULUK}

Bilindiği üzere toplumda/hukuk düzeninde bir uyuşmazlık ortaya çıktığı takdirde bunun vakit geçirilmeksizin giderilmesi gerekir. Ancak hukuk uyuşmazlıkları bakımından tasarruf ilkesi esas olduğundan, taraflar (davacı) bu uyuşmazlığı mahkemeye taşımadıkça mahkemenin uyuşmazlığa el atması mümkün değildir. Hukuk uyuşmazlıklarının çözümü bakımından dörtlü bir ayrım öngörülmektedir. Buna göre taraflar, uyuşmazlığı (1) kendi aralarında, (2) tarafsız ve bağımsız üçüncü kişinin katılımı ile ve gönüllülük esasına dayanarak, (3) tahkim yoluyla veya (4) mahkeme (devlet eliyle yargılama) aracılığı ile çözebilirler. Bunlardan dördüncüsü, yani devlet eliyle yargılama, diğer yollara başvurulamaması (örneğin tarafların üzerinde serbestçe tasarruf edemeyecekleri bir uyuşmazlık olması) veya bu yollardan bir sonuç alınamaması (tahkimin bağlayıcı olması esası bir tarafa bırakıırsa) ya da tarafların bu yollardan birine başvurmak istememeleri halinde kural olarak zorunludur. Bu zorunluluk hem taraflar bakımından hem de devlet bakımından geçerlidir. Nitekim Türkiye Cumhuriyeti Anayasası'nın 36. maddesine göre, "Herkes, meşrû vasıta ve yollardan faydalanmak suretiyle yargı mercileri önünde davacı veya davalı olarak iddia ve savunma ile adil yargılanma hakkına sahiptir. Hiçbir mahkeme, görev ve yetkisi içindeki davaya bakmaktan kaçınamaz."

Yukarıda bahsettiğimiz uyuşmazlık çözüm yollarından ikincisi, yani uyuşmazlığın tarafsız ve bağımsız üçüncü kişinin katılımı ile ve gönüllülük esasına dayanarak çözülmesi, günümüz kullanımıyla alternatif uyuşmazlık çözümlerini ifade etmektedir. Uyuşmazlığın, tarafların kendi aralarında veya alternatif çözüm yolları vasıtasıyla çözülmesinin, tahkim ve devlet eliyle yargılamaya kıyasla farklı bazı özellikleri ve avantajları bulunmaktadır. Bu yollar, tarafların uyuşmazlık çözüm sürecine doğrudan katılmaları ve süreçte egemen olmalarını sağlar; esnek ve ılımlı çözümler sunar, tarafların ilişkilerinin devam edebilmesini sağlar; uyuşmazlığın gizlilik çerçevesinde çözülmesi esastır; geçmişe (uyuşmazlığa) değil, geleceğe (uyuşmazlı̆̆ın çözümü ve ilişkilerin devamı) yöneliktir; taraflardan hangisinin haklı olduğu ile değil, her iki tarafın da elde edebileceği en iyi kazanımla ilgilenir; zaman ve masraflardan tasarruf edilmesini sağlar, yargı mercilerinin iş yükünün azaltılıp, daha kaliteli bir faaliyet yürütmelerine yardımcı olur; gönüllülük esastır, her hangi bir zorlama veya hükme varma söz konusu değildir; belli bir prosedür (yargılama usulü) bulunmaz, tarafların ve uyuşmazlığın özelliklerine göre farklı yaklaşımlar üretilir ve süreç sonunda ortaya çıkacak karar bakımından, yargıda olduğu gibi bir belirsizlik yoktur; taraflar isterlerse bir sonuca ulaşırlar (Özbek, 2013: 256 vd.).

Tahkim ve mahkeme dışındaki uyuşmazlık çözümlerinin Türk hukukundaki uygulaması nispeten yeni olmakla birlikte, geçmişinin 6325 sayılı Hukuk Uyuşmazlıklarında Arabuluculuk Kanunu’ndan çok daha geriye gittiği bilinmektedir.

Hukuk uyuşmazlıkları bakımından modern anlamda alternatif çözüm yollarının Türk hukukundaki uygulamasının en eskileri 1924 sayılı Köy Kanunu’nda bulunmaktadır. Bu Kanun'un 5. maddesinde müzakere, 48 ve 53. maddelerinde ise arabuluculuk uygulamaları düzenlenmiştir. Bu düzenlemeler dışında, 4787 sayılı Aile Mahkemelerinin Kuruluş, Görev ve Yargılama Usullerine Dair Kanun ile Gerçek Kişiler ve Özel Hukuk Tüzel Kişileri ile Kamu Kurum ve Kuruluşlarınca Açılacak Aile Danışma Merkezleri Yönetmeliği çerçevesinde aile uyuşmazlıkları bakımından, 6356 Sayılı Sendikalar ve Toplu İ̧̧ Sözleşmesi Kanunu'nda toplu iş uyuşmazlıkları bakımından arabuluculuk örnekleri düzenlenmiş; ayrıca Avukatlık Kanunu'nda 2001 yılında yapılan değişiklikle, avukatlara uzlaştırma yetkisi getirilmiştir. Avukatlık Kanunundaki bu düzenleme, avukatla temsil zorunluluğu olmayan hukuk sistemimizde avukatla temsilin zorunlu olduğu istisnai hallerden birisi olması sebebiyle de önem taşımaktadır.

Tebliğimizin konusunu oluşturan arabuluculuk kurumu, 6325 sayılı Hukuk Uyuşmazlıklarında Arabuluculuk Kanunu'nda yapılmış olan tanıma göre, sistematik teknikler uygulayarak, görüşmek ve müzakerelerde bulunmak amacıyla tarafları bir araya getiren, onların birbirlerini anlamalarını ve bu suretle çözümlerini kendilerinin üretmesini sağlamak için aralarında iletişim sürecinin kurulmasını gerçekleştiren, uzmanlık eğitimi almış olan tarafsız ve bağımsız bir üçüncü kişinin katılımıyla ve ihtiyarî olarak yürütülen uyuşmazlık çözüm yöntemini ifade eder. Arabuluculuk, alternatif uyuşmazlık çözüm yollarının içinde en temel ve en popüler olanıdır (Özbek, 2013: 555).

Arabulucu, hakem veya hâkimin aksine, uyuşmazlığın hukuki boyutu ile yani kimin haklı kimin haksız olduğu ile ilgilenmez; bilakis tarafların, aralarındaki uyuşmazlığı kendilerinin ve geleceğe yönelik olarak çözmelerine bir "ara-bulucu" olarak yardımcı olmakla yetinir. Arabulucunun belirli çözüm önerileri getirmesi de (en azından pozitif düzenleme bakımından) yasaktır; ancak aşağıda değineceğimiz İ̧ Mahkemeleri Kanunu Tasarı Taslağı'nda bu yasağın kaldırılması yönünde bir hüküm bulunmaktadır.

\section{6325 SAYILI HUKUK UYUŞMAZLIKLARINDA ARABULUCULUK KANUNU VE KAPSAMI}

Yukarıda bahsettiğimiz alternatif uyuşmazlık çözüm yollarına ek olarak, Kanun koyucu, 2012 yılında 6325 sayılı Hukuk Uyuşmazlıklarında Arabuluculuk Kanunu'nu kabul etmiş ve söz konusu Kanun 2013 yılında yürürlüğe girmiştir. Bu Kanun, hazırlanmasında sergilenen yaklaşım itibariyle de üzerinde çok tartışılması gereken bir kanundur. Kanun'un 3. maddesinin birinci fıkrasında iradi olma prensibi düzenlenmiş ve tarafların, arabulucuya başvurmak, süreci devam ettirmek, sonuçlandırmak veya bu süreçten vazgeçmek konusunda serbest oldukları ifade edilmiştir. Arabuluculuk, niteliği itibariyle 
gönüllülük ve uyuşmazlığın yargı sistemi dışında çözülmesi esaslarına dayanır. Oysaki kanun koyucunun, 6325 sayılı Kanun'un hazırlanmasında, sonuç esaslı bir yaklaşım sergilediği görülmektedir. Buna göre, Kanun'da arabuluculuğa elverişli/elverişli olmayan konular ile arabuluculuk sonunda imzalanacak bir anlaşmaya konu olabilecek/olamayacak konular arasında bir ayrım yapılmadığı görülmektedir. Bu sebeple arabuluculuğun konusu, dünyadaki genel uygulamanın aksine, son derece kısıtlı tutulmuştur.

6325 sayılı Kanun'a göre, şiddet iddiası içeren aile uyuşmazlıklarında, 5271 sayılı Ceza Muhakemesi Kanunu gereğince uzlaşma kapsamına girmeyen bir suç ile ilgili konularda, medeni hukuktan doğan ve kamu düzenini ilgilendiren nesep, boşanma, ahvali şahsiye gibi davalarda, hukuka ve ahlaka aykırı sözleşmelerden doğan konularda, çekişmesiz yargı işlerinde, taşınmaz mülkiyetinin devri sonucunu doğuracak konularda, iflas davalarında (ve iflasa alternatif olan ve iï'ndan doğan diğer külli icra yollarında) ve kamu düzenini ilgilendiren diğer uyuşmazlıklarda (İmar Kanunu, derneklerin kapatılması vs.) arabuluculuğa başvurulamaz.

Tahkim bakımından konu tabanlı bir sınırlama yapılması mümkün ve hatta gerekli olmakla birlikte (örneğin iş veya tüketici uyuşmazlıkları) aynı yaklaşımın arabuluculuk konusunda gösterilmesi kanımızca uygun değildir. Zira sonuç bakımından tahkim bağlayıcı bir yolken, arabuluculuk değildir. Hatta arabuluculukta, yukarıda da bahsettiğimiz üzere, işin sonunda bir anlaşma belgesi hazırlanmasına dahi ihtiyaç yoktur; taraflar uyuşmazlığı bir belge olmadan da ortadan kaldırabilirler. Bu sebeple kanımızca, arabuluculuğun kapsamının genişletilmesi gerekmektedir. Nitekim aşağıda değineceğimiz i̇ş Mahkemeleri Kanunu Tasarı Taslağında, Ceza Muhakemesi Kanunu bağlamında yapılmış olan sınırlamanın kaldırılması yönünde bir hüküm bulunmaktadır.

6325 sayılı Kanun’a göre arabuluculuğun temel ilkeleri dört başlıkta özetlenebilir. Bunlar; (1) iradi olma, (2) eşitlik, (3) gizlilik ve (4) beyan ve belgelerin daha sonra kullanılamamasıdır. Bunlardan dördüncüsü, yani arabuluculuk görüşmeleri sırasında elde edilen belge ve bilgilerin yargılamada kullanılamaması hali ayrı bir önem taşımaktadır. Bu hususa bilahare geri döneceğiz.

Arabuluculuk uygulamasına başvurulmuş olması hali, Kanun tarafından beklenilmesi gereken bir hal olarak düzenlenmiştir. Kanun'un 16. maddesine göre, "arabuluculuk süreci, dava açılmadan önce arabulucuya başvuru hâlinde, tarafların ilk toplantıya davet edilmeleri ve taraflarla arabulucu arasında sürecin devam ettirilmesi konusunda anlaşmaya varılıp bu durumun bir tutanakla belgelendirildiği tarihten itibaren işlemeye bașlar. Dava açılmasından sonra arabulucuya başvuru hâlinde ise bu süreç, mahkemenin tarafları arabuluculuğa davetinin taraflarca kabul edilmesi veya tarafların arabulucuya başvurma konusunda anlaşmaya vardıklarını duruşma dışında mahkemeye yazılı olarak beyan ettikleri ya da duruşmada bu beyanlarının tutanağa geçirildiği tarihten itibaren işlemeye başlar. Arabuluculuk sürecinin başlamasından sona ermesine kadar geçirilen süre, zamanaşımı ve hak düşürücü sürelerin hesaplanmasında dikkate alınmaz". Ayrıca Kanun'un 15. maddesinin beşinci fıkrasına göre, "dava açıldıktan sonra tarafların birlikte arabulucuya başvuracaklarını beyan etmeleri hâlinde yargılama, mahkemece üç ayı geçmemek üzere ertelenir. Bu süre, tarafların birlikte başvurusu üzerine üç aya kadar uzatılabilir".

Tarafların arabuluculuk faaliyeti çerçevesinde anlaşmaları halinde bir anlaşma belgesi imzalanabilir. Kanun'un 18. maddesinde düzenlenmiş olan bu belge, hukuki nitelik olarak bir özel hukuk sözleşmesidir ve mahkeme dışı sulh sözleşmesi ile benzerlik taşır. Arabuluculuk faaliyetine dava devam ederken gidilmiş ise, taraflar diledikleri takdirde bu anlaşmayı mahkemeye taşıyıp mahkeme içi sulh halinde de getirebilirler. Arabuluculuk faaliyeti sonunda hazırlanan ve imzalanan anlaşma belgesi, Avukatlık Kanunu m. 35/A düzenlemesinden farklı olarak, tek başına ilam niteliğinde belge değildir. Bu belgenin ilam niteliği haiz belge özelliğini taşıması, mahkemece verilecek olan "icra edilebilir" şerhi sonrasında gerçekleşir.

\section{1 MAYIS 2017 ITIBARIYLE TÜRKIYE'DE ARABULUCULUK UYGULAMALARI VE IŞ MAHKEMELERI KANUNU TASARI TASLAĞI}

Arabuluculuk Kurumu'nun yayınladığı son verilere göre, Türkiye'de 1 Mayıs 2017 itibariyle, 2.949'u Ankara, İstanbul ve İzmir'de olmak üzere, 5.268 arabulucu sicile kayıtlı olarak görev yapmaktadır. Bu verilere göre, üç büyük il dışında sadece 2.319 kayıtlı arabulucu bulunmaktadır. Ayrıca yine söz konusu veriler incelendiğinde, illerin bir kısmında hiç ise hiç kayıtlı arabulucu bulunmadığı görülmektedir. Arabulucu istatistikleri il tabanlı yayınlandığı için, ilçeler bakımından elimizde herhangi bir veri bulunmamaktadır.

Kurumun eline şu ana kadar 12.005 arabuluculuk dosyası ulaşmış ve bu dosyaların 11.240'ı anlaşma ile sonuçlanmıştır. Anlaşma sağlanamayan ise yalnızca 765 adet arabuluculuk uygulaması bulunduğu rapor edilmiştir. Bu rakamlar konu bazında incelendiğinde çok ilginç bir sonuç ortaya çıkmaktadır. Söz konusu arabuluculuk uygulamalarının 10.684 adedini, yani yaklaşık \%89'unu işçi-işveren uyuşmazlıkları oluşturmaktadır. Ancak bu dosyalar nitelikleri gereği gizli olduklarından içerikleri konusunda herhangi bir veri bulunmamaktadır. Kurumun yayınladığı diğer bir veri de uygulamaların illere göre dağılımıdır. Buna göre, uygulamaların 4.850'sinin, yani yaklaşık \%40'ının İstanbul'da olduğu rapor edilmiştir. 
Hemen hemen dört yılda ulaşılan yaklaşık on iki bin dosya sayısı az olarak nitelendirilebilecek de olsa, \%93'ün üzerindeki başarı oranının son derece olumlu olduğu tartışmadan uzaktır.

Yukarıdaki istatistiklerin yarattığı olumlu havanın da etkisi ile Adalet Bakanlığı zorunlu arabuluculuk konusunda bir çalışma yapmış ve hazırlanmış olan İş Mahkemeleri Kanunu Tasarı Taslağı'nda bu yönde hükümlere yer verilmiştir (http://www.adalet.gov.tr/tasarilar/20160323-isMahkemeleriKanunuTasarisi-DuzmetinGerekce.pdf). $2016 \quad$ yılında hazırlanan ve görüşe gönderilen ancak bu tebliğin hazırlandığı tarih itibariyle henüz Türkiye Büyük Millet Meclisine sunulmamış olan olan tasarı taslağında, bazı iş uyuşmazlıkları hakkında önce arabulucuya başvurulmuş olması bir dava şartı haline getirilmektedir. Tasarı taslağının "Zorunlu Arabuluculuk" başlığını taşıyan 3. maddesine göre:

"Kanuna, bireysel veya toplu iş sözleşmesine dayanan iş̧̧i alacağı ile işe iade talebiyle açılacak davalarda, dava açılmadan önce arabuluculuğa başvurmak zorunludur..

Başvuru karşı tarafın, karşı taraf birden fazla ise bunlardan birinin yerleșim yerindeki veya işin yapıldığı yerdeki arabuluculuk bürosuna, arabuluculuk bürosu kurulmayan yerlerde ise adli yargı ilk derece mahkemesi adalet komisyonu tarafından görevlendirilen sulh hukuk mahkemesi yazı işleri müdürlüğüne yapılır...

Arabulucu, yapılan başvuruyu görevlendirildiği tarihten itibaren üç hafta içinde sonuçlandırır. Bu süre zorunlu hallerde arabulucu tarafindan en fazla bir hafta uzatılabilir.

Tarafların arabulucu huzurunda anlaşmaları halinde, arabuluculuk ücreti, Arabuluculuk Asgari Ücret Tarifesinin ikinci Kısmına göre aksi kararlaştırılmadıkça taraflarca eşit şekilde karşılanır. Bu durumda ücret, Tarifenin Birinci Kısmında belirlenen iki saatlik ücret miktarından az olamaz. Tarafların arabulucu huzurunda anlaşamaması halinde ise, arabuluculuk görüşmelerinin ilk iki saatlik bölümü Hazineden, iki saati aşan kısmı ise aksi kararlaştırılmadıkça taraflarca eşit şekilde, Arabuluculuk Asgari Ücret Tarifesinin Birinci Kısmına göre karşılanır. Hazineden karşılanan ve taraflarca ödenen arabuluculuk ücreti, yargılama giderlerinden sayılır.

Geçerli bir mazeret göstermeksizin arabuluculuk görüşmelerine katılmayan taraf son tutanakta belirtilir ve davada lehine karar verilmiş olsa bile, yargılama giderinin tamamını ödemeye mahkûm edilir

Arabuluculuk ücretini karşılamak için adli yardıma ihtiyaç duyan taraf, arabuluculuk bürosunun bulunduğu yerdeki sulh hukuk hâkiminin kararıyla adli yardımdan yararlanabilir...".

Tasarı taslağındaki düzenleme ile önce arabulucuya başvurulmasının bir dava şartı haline getirilmesi ile yetinilmemiş; ayrıca taraflardan birinin bu arabuluculuk faaliyetine katılmaması bir "kötüniyet" hali olarak kabul edilerek, dava sonundaki yargılama giderlerinin yükletilmesi şeklinde bir yaptırım da öngörülmüştür.

Ancak burada ifade edilmesi gerekir ki zorunluluk unsuru, sadece başvuru aşaması bakımından söz konusu olacaktır. Arabuluculuk faaliyetinin sona erdirilmesi veya sonuç bakımından herhangi bir bağlayıcılığın söz konusu olması düşünülemez; böyle bir yaklaşımın Anayasa'nın 36. maddesine aykırılık doğuracağı da açıktır.

\section{DÜNYADA ZORUNLU ARABULUCULUK UYGULAMALARI VE KONUYA GENEL YAKLAŞIM}

Tespit edebildiğimiz üzere, dünyada şu anda gerçek anlamda zorunlu arabuluculuğun uygulandığı üç hukuk sistemi bulunmaktadır. Gerçek anlamda dememizdeki kasıt, aşağıda bahsedeceklerimiz dışındaki diğer bazı hukuk sistemlerinde, usuli anlamda bir zorlama bulunmamakla birlikte, tarafların arabuluculuğa yönlendirildiği, tarafların arabuluculuk konusundaki istemsiz tavırlarının ise daha sonra yargılamadaki giderlerin yükletilmesinde takdir edildiği ingiltere ve Avustralya gibi örneklerin bulunmasıdır (Quek, 2010: 489; Hanks: 947; Drummond, çevrimiçi). Ancak bunlar gerçek anlamda zorunlu arabuluculuk olarak değerlendirilemeyeceği için çalışmamızın dışında bırakılmıştır.

Gerçek anlamda zorunlu arabuluculuğu uygulayan hukuk sistemleri, ABD’nin California ve Kanada'nın Ontario Eyaletleri ile İtalya'dır. California'daki sistem 1981, Ontario'daki ise 1999 yılından beri uygulanmaktadır. California'da zorunluluk özellikle aile uyuşmazlıkları (velayet ve çocukla kişisel ilişki kurulması) bakımından bulunmakla birlikte, Ontario'daki uygulama, tam tersine, aile uyuşmazlıklarını dışarıda bırakacak ve hemen hemen diğer tüm hukuk uyuşmazlıklarını içerecek şekilde oluşturulmuştur. California'daki düzenleme, aile içi şiddet içeren uyuşmazlıkları da kapsaması sebebiyle çok ciddi eleştirilere maruz kalmaktadır (Germane, Johnson, Lemon, 2013: 175-200). Ontario'daki uygulama ise, tüm eyaleti kapsayacak şekilde değil, sadece Toronto, Ottawa ve Windsor şehirleri bakımından geçerli olması sebebiyle de ilginçlik arz etmektedir.

California ve Ontario uygulamaları hakkında hem olumlu görüşler hem de ciddi eleştiriler bulunmaktadır. Amerikalı ve Kanadalı hukukçular zorunluluğun, arabuluculuğun doğasına aykırı olduğunu, "zorunlu arabuluculuk" kavramını bir "oksimoron" olarak niteleyerek ifade etmektedirler (Winestone, çevrimiçi; ayrıca bu konu hakkında daha ayrıntılı bir çalışma için bkz. Quek, 2010). 
Ayrıca hemen belirtmemiz gerekir ki, ABD ve Kanada hukuklarının da içinde yer aldığı anglo-sakson yargılama sistemlerinde, uyuşmazlıkların dava dışı yollarla çözümü son derece yaygındır. Bu konuda farklı istatistikler olmakla birlikte, dava dışı çözüm oranının \%99'lara kadar ulaşabildiği görülmektedir (Hensler, 2010: 535; Maxeiner, 2012: 295). Dolayısıyla bu hukuk sistemlerindeki başarı rakamlarının, dava dışı uyuşmazlık çözümlerinin yüzde onları bile bulmadığı Türk hukuk yargılaması bakımından ne denli örnek alınabileceği tartışılır niteliktedir.

İtalya'daki durum ise çok daha farklıdır. İtalya söz konusu uygulamayı Mart 2011'den itibaren geçerli olacak şekilde bir kanun hükmünde kararname ile getirmiş, ancak söz konusu kanun hükmünde kararname İtalyan Anayasa Mahkemesince iptal edilmiştir. Bununla birlikte zorunluluk, Eylül 2013'ten geçerli olmak üzere ve dört yıllık bir deneme süresinde geçerli olacak şekilde, ayrıca kapsamı daraltılarak yeniden getirilmiştir (Svatos, çevrimiçi). Mart 2011 - Mart 2012 arasında başvurulan doksan binden fazla arabuluculuk uygulamasının sadece \%35'lik kısmında tarafların bir araya geldikleri, tarafların bir araya geldikleri uygulamaların ise \%48'inin anlaşma ile sonuçlandığı rapor edilmektedir (de Berti, çevrimiçi). Diğer bir istatistiğe göre, Mart 2011- Ekim 2012 arasında 215.689 uyuşmazlıkta arabuluculuğa başvurulmuş, toplam \%12 başarı oranı elde edilmiştir (Morek, çevrimiçi).

İtalya uygulamasındaki çok önemli diğer bir özellik de, arabulucunun anlaşmazlık halinde bir çözüm önerisi getirebilmesidir. Taraflar bu öneriye uymaz ve yargılamaya gidilirse, yargılama sonunda takdir edilecek yargılama giderlerinin yükletilmesinde, bu önerinin reddedilmiş olması hali, davaya bakan mahkeme tarafından takdir edilebilmektedir (Svatos, çevrimiçi).

\section{ZORUNLU ARABULUCULUK UYGULAMASININ YARATABILECEĞI SIKINTILAR}

\subsection{Gönüllü Arabuluculuk ve Zorunlu Arabuluculuğun Temelde Aynı Şey Olmamaları}

Arabuluculuğun yukarıda giriş kısmında saydığımız faydalarının bir kısmı, zorunlu arabuluculuk için değil, sadece gönüllü arabuluculuk için geçerlidir (Hardy, çevrimiçi). Bu tebliğde atıf yaptığımız ve yapmadığımız, konu hakkında yazıımış eserlerin büyük kısmında, gönüllülük esası ile çalışan arabuluculuk (veya tüm diğer alternatif uyuşmazlık çözüm yolları) ile zorunlu arabuluculuk arasında keskin bir ayrım yapıldığı görülmektedir. Sonuçtaki başarı oranının iki tür arabuluculuk arasında farklı olacağı zaten açıktır, ancak mesele bundan daha önemli bir boyut arz etmektedir:

Gönüllü arabuluculukta taraflar kendi istekleri ile bu yola başvururlar ve ortaya çıkabilecek sonuca da hazırlıklı olurlar, oysaki zorunlu arabuluculukta taraflar bu yola gönülsüz olarak giderler ve daha sonra yargılamada ortaya çıkabilecek sonuçlar ve olası baskıdan etkilenerek arabuluculukta ortaya çıkabilecek sonucu kabullenmek zorunda kalabilirler. Sosyal ve kültürel bağların çok kuvvetli olduğu toplumumuzda bunun ne gibi sonuçlar doğurabileceğini kestirmek çok zor olmasa gerekir. Gönüllü arabuluculuk bakımından da böyle bir baskı elbette olabilir ancak "ası"” yol dava açmak olduğu için bu baskıdan güçsüz olan tarafın kurtulabilmesi daha kolaydır. Oysaki zorunlu arabuluculukta güçsüz olan taraf bu baskıyı çok daha fazla üzerinde hissedecektir. Bu da beraberinde Anayasa'nın 36. maddesinde düzenlenmiş olan hak arama hürriyetine dolaylı da olsa bir aykırılık oluşturacaktır.

Gönüllü arabuluculukta sahip olduğumuz yaklaşık \%93'lük olağanüstü başarı oranının zorunlu arabuluculuk ile ciddi oranda azalacağı açıktır; ancak burada sorun, arabuluculuğa olan güvenin sarsılması üzerine, gönüllü olarak gidilen arabuluculuk hallerinde de başarı oranının düşüp düşmeyeceğidir. Yani zorunlu arabuluculuk uygulamasının, gönüllü arabuluculuk uygulamasını zehirlemesi de çok kuvvetli bir olasııık olarak önümüzde durmaktadır.

\subsection{Mevcut İstatistikler Çerçevesinde Zorunlu Arabuluculuk Uygulamasının Kısa Vadede "İmkânsız" OIması}

Adalet Bakanlığı istatistiklerine göre, Türkiye'de 2015 yılı içerisinde iki milyonun üzerinde dava açılmıştır. Bu davaların yaklaşık \%10'unu iş mahkemelerinde açılmış olan davalar oluşturmaktadır (http://www.adlisicil.adalet.gov.tr/istatistik_2015/HUKUK\%20MAHKEMELER\%C4\%B0/1.pdf). Çok iyimser bir tahminle bu davaların üçte ikisi zorunlu arabuluculuk uygulamasına tâbi olsa bile, yılda yüz elli bine yakın uyuşmazlık hakkında önce arabulucuya başvurulması söz konusu olacaktır. Yukarıda da ifade ettiğimiz üzere, Mayıs 2017 itibariyle Türkiye'de sicile kayıtlı arabulucu sayısı sadece 5.268'tir. Daha da önemlisi, bunların sadece 2.319 adedi Ankara, İstanbul ve İzmir dışındaki illerde bulunmakta ve bazı illerde ise hiçbir arabulucu görev yapmamaktadır. Ayrıca diğer konulardaki gönüllü arabuluculuğun da devam edeceği göz önüne alındığında mevcut sayının yetersiz olacağı açıktır. Az sayıdaki arabulucunun mevcut işleri yetişmesi neredeyse imkânsız olmakla birlikte, ortaya çıkacak hizmetin kalitesinin ne olacağı da aşağı yukarı kestirilebilir. Zaten ülkemizde yaklaşık dört yıllık süre içerisinde on iki bine ancak ulaşan uygulaması bulunan sistematik arabuluculukta ne gibi bir tecrübe edinilmiş (veya daha doğru bir ifade ile edinilmemiş) olduğu da tartışmadan uzaktır.

Zorunlu arabuluculuk uygulaması ile çok yoğun iş yükü altında bulunan ve/veya tecrübesiz olan arabuluculara gidildiğinde, tarafların 6325 sayılı Kanun'da düzenlenmiş olan haklarının ne kadar korunabileceği konusu üzerinde mutlaka çok dikkatlice düşünülmesi gereken bir husustur. 


\subsection{Mevcut Şekliyle Uygulanacak Olan Zorunlu Arabuluculuğun Yargının İ̧̧ Yükünü Ciddi Oranda Azaltmayacak Olması}

Yukarıda da bahsettiğimiz üzere, 6325 sayılı Kanun'da düzenlenmiş olan arabuluculuk sisteminde sonuç bakımından çok önemli bir sorun bulunmaktadır; imzalanan anlaşma, kendi başına ilam niteliğinde belge değildir. Anlaşma belgesinin bu niteliği kazanabilmesi, mahkeme tarafından verilecek olan icra edilebilirlik şerhine bağlıdır. Bu çerçevede mahkemelerin iş yükünün tamamen ortadan kalkacağı kesinlikle söylenemez. Elbette mahkemenin bu çerçevede yapacağı inceleme gerçek anlamda bir uyuşmazlık çözümü olmayacaktır; ancak bir yargılama faaliyeti yapıldığı açıktır. Ayrıca mahkemelerin bu şerhi verme işlemi sırasında uygulamada ne gibi incelemeler yaptıkları veya yapacakları konusunda da elimizde henüz yeterli bir veri bulunmamaktadır.

Yine mahkeme dışı sulhe benzediğini ifade ettiğimiz (ve gönülsüz olarak yapılması muhtemel olan) bu anlaşmalara uyulmaması veya şarta bağlı durumların varlığı gibi hallerde bunların da yargı önüne getirilmesi kaçınılmaz olacaktır.

İkinci mesele, arabuluculuk faaliyeti sırasında geçecek olan zamandır. Bu şekilde bir zaman kaybı elbette arabuluculuğun niteliği gereğidir ve gönüllü arabuluculukta bu süre kaybı taraflar bakımından çoğu zaman sıkıntı yaratmayacaktır; zira tarafların arabuluculuk yoluna gönüllü olarak başvurdukları için, faaliyet sonunda bir sonuç alınamasa bile, zaman kaybına "en azından denedik" mantığı ile yaklaşmaları normaldir. Oysaki zorunlu arabuluculuk uygulamalarının büyük bir kısmı başarısızlıkla sonuçlanacağı için, zaten çok uzun olan ve Avrupa İnsan Hakları Mahkemesinin "uzun yargılama süreleri" kıstasları bakımından sınırlarda gezinen ülkemiz hukuk yargılamasındaki yargılama süreleri, daha da uzayacaktır. Tarafların isteği dışında ortaya çıkacak olan bu zaman kaybı ve bunun da beraberinde getireceği ek masraflar, yine anayasal (Anayasa m. 141) bir ilke olan ve adil yargılanma hakkının da ayrılmaz bir parçasını oluşturan "usul ekonomisi ilkesi"nin ihlal edilmesi sonucuna yol açar.

\subsection{Sistematik Arabuluculuk Konusundaki Tecrübe Eksikliği Ve Özellikle "Beyan ve Belgelerin Daha Sonra Kullanılamaması" Kuralının Önemi}

Kanun tarafından tanınan alternatif uyuşmazlık çözümleri bakımından var olan en önemli kurallardan birisi, bu yoldaki görüşmeler sırasında söylenen sözlerin ve sunulan ya da meydana getirilen belgelerin daha sonra yapılacak olan yargılamaya getirilemeyeceği ilkesidir. Bu ilke, 6325 sayılı Kanun'da da yer almaktadır. Kanun'un 5. maddesine göre, taraflar, arabulucu veya arabuluculuğa katılanlar da dâhil üçüncü bir kişi, uyuşmazlıkla ilgili olarak hukuk davası açıldığında yahut tahkim yoluna başvurulduğunda, aşağıdaki beyan veya belgeleri delil olarak ileri süremez ve bunlar hakkında tanıklık yapamaz:

"1.Taraflarca yapılan arabuluculuk daveti veya bir tarafın arabuluculuk faaliyetine katılma isteği.

2.Uyuşmazlığın arabuluculuk yolu ile sona erdirilmesi için taraflarca ileri sürülen görüşler ve teklifler.

3.Arabuluculuk faaliyeti esnasında, taraflarca ileri sürülen öneriler veya herhangi bir vakıa veya iddianın kabulü.

4.Sadece arabuluculuk faaliyeti dolayısıla hazırlanan belgeler."

Yine Kanun'a göre, bu bilgilerin açıklanması mahkeme, hakem veya herhangi bir idari makam tarafından istenemez. Bu beyan veya belgeler, yukarıda öngörülenin aksine, delil olarak sunulmuş olsa dahi hükme esas alınamaz. Ancak, söz konusu bilgiler bir kanun hükmü tarafından emredildiği veya arabuluculuk süreci sonunda varılan anlaşmanın uygulanması ve icrası için gerekli olduğu ölçüde açıklanabilir.

Tarafların gönülsüz olduğu ve özellikle de tecrübesiz bir arabulucu önünde yapılacak görüşmeler bakımından bu hükmün daha sonra görülecek davada sıkıntı yaratacağı da açıktır. Zira bu ilkenin varlığının temelinde, tarafların anlaşmaya hazır oldukları varsayımı yatmaktadır. Anlaşmaya hazır olan taraflar, bu hüküm sayesinde görüşmelerde kendilerini daha rahat ifade edebilirler.

Ayrıca aynı hüküm bakımından diğer önemli bir husus da, yukarıda belirtilen sınırlamalar saklı kalmak koşuluyla, hukuk davası ve tahkimde ileri sürülebilen delillerin, sadece arabuluculukta sunulmaları sebebiyle kabul edilemeyecek deliller haline gelmeyeceklerin de düzenlenmiş olmasıdır. Bu hüküm son derece önemli ve gerekli olmakla birlikte, hükmün, "gönülsüz" katılımcılar tarafından hem delillerin gereksiz yere sunulması, hem de bunların mahkemede sunulmasına engel olunmaya çalışılması bağlamında suiistimal edilmeye son derece açık bir hüküm olduğu söylenebilir.

\section{SONUÇ VE ÖNERILER}

Şu anda Türk hukuk yargılamasında, zorunlu arabuluculuğun yanı sıra, küçük talepler yargılama usulü, yeni bir İcra ve iflas Kanunu hazırlanması ve yargıda zaman yönetimi projesi gibi çok sayıda çalışma yapıldığı kamuoyunca bilinmektedir. Bu çalışmalar, zorunlu arabuluculuk gibi bir bilinmez olmaktan uzak, yargılamanın gerçekten daha hızlı ve daha etkin sağlanmasına katkı sağlayacağı tahmin edilen (ve kuvvetle umulan) çalışmalardır. Bu çalışmalar henüz sonuçlanmadan ve etkileri görülmeye başlanmadan, zorunlu arabuluculuk gibi, birkaç hukuk sistemi dışında dünyada örneği bulunmayan bir 
uygulamanın sisteme "zorla" entegre edilmesi kanımızca son derece sakıncalı olacaktır. Sistem denenebilir ve başarısız olduğu anlaşıldıktan sonra kaldırılabilir; ancak bu arada uğranılan hak kayıpları ve daha da önemlisi, "gönüllü" arabuluculuk kurumunun kamuoyunda uğradığı güven kaybının geri getirilebilmesi, en azından kısa ve orta vadede imkânsız olacaktır.

Ayrıca belirttiğimiz üzere mevcut arabulucu ve uyuşmazlık sayıları da dikkate alındığında, bu uygulamanın kısa vadede mümkün olmadığı da açıktır. Aksi durum, Anayasa'nın hak arama hürriyeti ve usul ekonomisi ilkelerine de aykırılık oluşturacaktır.

Burada yapılması gereken şey, öncelikle, arabuluculuk uygulamasının oturmasını beklemek ve onu özendirmeye çalışmaktır. Ayrıca unutulmaması gerekir ki arabuluculuk tek alternatif uyuşmazlık çözümü değildir. Uyuşmazlığın ve tarafların niteliklerine ve durumlarına göre farklı çözüm yollarının da denenmesi veya önerilmesi gerekir. Bu çerçevede özellikle Avukatlık Kanunu m. 35/A'da düzenlenmiş olan uzlaştırma kurumunun da etkin hale getirilmesi, tüm alternatif uyuşmazlık çözüm yolları bakımından hâkimlerin ve avukatların eğitilmesi; bunların da, uyuşmazlığın taraflarını aktif şekilde alternatif yollara teşvik etmelerinin önünün açılması gerekir. Uygulamada pek çok hâkim, "ihsas-ı rey" kurumundan çekindikleri için tarafları sulh ve arabuluculuğa teşvik edemediklerini ifade etmektedirler. Zorunlu arabuluculuk uygulamaları bulunan hukuk sistemlerinde, özellikle anglo-sakson ülkelerinde, "gönüllü" arabuluculuğun çok uzun yıllardır uygulanır olduğu, bu yerleşik uygulamaların gösterdiği başarı üzerine sistemin bazı uyuşmazlıklar bakımından "zorunlu" hale getirildiği görülmektedir. Ülkemizde gördüğümüz \%93'lük başarı oranı bu konuda bize hiçbir şekilde yol gösterici olamaz; zira bu oran sadece dört yıllık bir uygulama ve toplam on iki bin uyuşmazlık hakkında ortaya çıkan bir istatistikten ibarettir.

Yargılamanın hızlandırıması isteniyorsa, bu konuda "zorunlu arabuluculuk"tan önce atılacak adımlar olduğu açıktır. Bu bağlamda, hâkim sayısının arttırılması; uyuşmazlıkların doğduktan sonra mahkeme önüne gitmesini engelleyecek değil, uyuşmazlığın hiç doğmamasını sağlayacak idari denetim gibi önlemlerin alınması (örneğin SGK, BDDK, SPK, RK vb. denetimlerinin arttırılması ve verilecek cezaların daha caydırıcı hale getirilmesi); HMK m. 29, 327 ve 329'da düzenlenmiş olan tarafların ve vekillerinin davada dürüst davranma ödevi ile dürüstlük kuralına aykırı dava açılması ve kötü niyetle cevap verilmesine yaptırım uygulanması hallerinin işler hale getirilmesi; yargılamanın daha hızlı yürümesini sağlayacak usuli değişikliklerin yapılması (örneğin yazılı yargılama usulünün uygulandığı bir davada tarafların talebi üzerine basit yargılama usulünün uygulanması ve küçük talepler için daha hızı bir yargılama usulü getirilmesi); davaların gecikmesi bakımından Devletten kaynaklanan en önemli sebep olan tebligat konusunun tamamen yeniden düzenlenmesi gibi öneriler kolaylıkla getirilebilir.

\section{KAYNAKLAR}

de Berti, G., "Mandatory mediation: the Italian experience, two years on", http://www.internationallawoffice.com/Newsletters/Arbitration-ADR/I (Erişim tarihi: 01.03.2017)

Drummond, I., "Should mediation be mandatory?", http://www.lexology.com/library/detail.aspx?g=68019975-f314-4d43-8966483af9e95667 (Erişim tarihi: 14.02.2017).

Germane, C., Johnson, M., Lemon, N., (2013), “Mandatory Custody Mediation and Joint Custody Orders in California: The Danger for Victims of Domestic Violence", Berkeley Journal of Gender, Law \& Justice, Vol. 1, No. 1.

Hanks, M., (2012), “Perspectives On Mandatory Mediation” , UNSW Law Journal Volume 35(3).

Hardy, W., “Mandatory Mediation”, http://willhardy.com.au/legal-essays/mandatory-mediation/view/ (Erişim tarihi: 14.02.2017).

Hensler, D.R., (2010), "USA National Report", The Costs and Funding of Civil Litigation (Editors: C. Hodges, S. Vogenauer, M. Tulibacka), Oxford.

Maxeiner, J.R., (2012), "The American 'Rule': Assuring the Lion His Share”, Cost and Fee Allocation in Civil Procedure (Editor: M. Reimann), New York.

Morek, R., "Mandatory Mediation in Italy - Reloaded", http://kluwermediationblog.com/2013/10/09/mandatory-mediation-in-italyreloaded/ (Erişim tarihi: 14.02.2017).

Özbek, M., (2013), Alternatif Uyuşmazlık Çözümü, 3. Baskı, Ankara.

Quek, D., (2010), “Mandatory Mediation: An Oxymoron? Examining The Feasibility Of Implementing A Court-Mandated Mediation Program", Cardozo Journal Of Conflict Resolution, Vol. 11, No. 2.

Svatos, M., “Mandatory Mediation Strikes Back”, http://www.mediate.com/articles/SvatosM1.cfm (Erişim tarihi: 14.02.2017).

Winestone, J., "Mandatory Mediation: A Comparative Review of How Legislatures in California and Ontario are Mandating the Peacemaking Process In Their Adversarial Systems", http://www.mediate.com/articles/WinestoneJ4.cfm (Erişim tarihi: 14.02.2017). 